\title{
LEVEL OF EVIDENCE IN THE PLACEMENT OF TRANSPEDICULAR SCREWS IN SUBAXIAL CERVICAL SPINE
}

\author{
NÍVEL DE EVIDÊNCIA NA COLOCAÇÃO DE PARAFUSOS PEDICULARES NA COLUNA \\ CERVICAL SUBAXIAL
}
NIVEL DE EVIDENCIA DE LA COLOCACIÓN DE TORNILLOS TRANSPEDICULARES EN LA COLUMNA CERVICAL SUBAXIAL

Cristóbal Herrera Palacios', Armando Fabio Ramos Guerrero1, Gustavo Casas Martinez ${ }^{1}$, Alfredo Javier Moheno Gallardo', Silvestre Fuentes Figueroa ${ }^{1}$

1. Hospital de Traumatología de la UMAE “Dr. Victorio de la Fuente Narváez", Cirugía de Columna Vertebral, IMSS, México, DF.

\begin{abstract}
The high-energy trauma mainly involves vertebral lesions and 6\% occur in the cervical region. This poses a challenge to spine surgeons in surgical decision-making, both in terms of approach as the instrumentation. International recommendations establish that the procedures performed are reproducible, safe, and effective. The techniques for placement of pedicle screws are complicated and have been based on intraoperative navigation (limited by cost) and fluoroscopy (greater exposure of health care professionals and patients to radiation). Therefore, the freehand technique is an option. The goal was to identify the level of evidence and grade of recommendation in the medical literature regarding the safety and efficacy of pedicle screw instrumentation with freehand technique in subaxial cervical spine. To this end, we carried out a systematic review with the following MeSH terms: safety, efficacy, vertebral artery. Articles were evaluated twice in a standardized and blind way by two observers skilled in systematic analysis, after CLEIS 3401 authorization in November 2014. Due to the nature of the study and the variables, articles with a high level of evidence and grade of recommendation were not found. Level of Evidence obtained on safety and efficacy in the placement of pedicle screws in subaxial column with freehand technique: $2 \mathrm{~b}$. Degree of Recommendation obtained on safety and efficacy in the placement of pedicle screws in subaxial column with freehand technique: B, favorable recommendation.
\end{abstract}

Keywords: Safety; Vertebral artery; Pedicle screws; Cervical vertebrae.

\section{RESUMO}

Os traumas de alta energia envolvem principalmente lesões vertebrais, sendo que $6 \%$ ocorrem na região cervical. Isso impõe um desafio aos cirurgiões de coluna na tomada de decisão cirúrgica, tanto em relação ao acesso quanto à instrumentação. As recomendações internacionais estabelecem que os procedimentos realizados sejam reprodutíveis, seguros e eficazes. As técnicas de colocação de parafusos pediculares são complicadas e têm se baseado em navegação transoperatória (limitada pelo custo) e fluoroscopia (maior exposição de profissionais de saúde e pacientes à radiação). Portanto, a técnica à mão livre é uma opção. O objetivo foi identificar o nível de evidência e o grau de recomendação na literatura médica referente à segurança e à eficácia da instrumentação de parafusos pediculares com a técnica à mão livre na coluna cervical subaxial. Para tanto, realizou-se uma revisão sistemática com os seguintes descritores do MeSH: segurança, eficácia, artéria vertebral. Os artigos obtidos foram duplamente avaliados de modo padronizado e cego por dois observadores especialistas em análise sistemática, depois de autorização CLEIS 3401, em novembro de 2014. Devido à natureza do estudo e das variáveis não foram encontrados artigos com alto nível de evidência e grau de recomendação. Nível de evidência obtido sobre segurança e eficácia na colocação de parafusos pediculares na coluna subaxial com técnica à mão livre: 2b. Grau de recomendação obtido sobre segurança e eficácia na colocação de parafusos pediculares na coluna subaxial com técnica à mão livre: B, recomendação favorável.

Descritores: Segurança; Artéria vertebral; Parafusos pediculares; Vértebras cervicais.

\section{RESUMEN}

Los traumas de alta energía implican principalmente lesiones de columna vertebral, de las cuales $6 \%$ se producen en la región cervical. Esto ha impuesto un reto para los cirujanos de columna en la toma de decisiones quirúrgicas, tanto en lo que se refiere a la vía de acceso cuanto a la instrumentación. Las recomendaciones internacionales establecen que los procedimientos sean reproducibles, seguros y eficaces. Las técnicas de colocación de tornillos transpediculares son complicadas y se han apoyado en la navegación transoperatoria (limitada por el costo) y la fluoroscopia (con mayor exposición de profesionales de salud y pacientes a la radiación). Por ello, la técnica de manos libres es una opción. El objetivo fue identificar el nivel de evidencia y grado de recomendación en la literatura médica respecto a la seguridad y eficacia de la instrumentación con tornillos transpediculares en la columna subaxial con técnica de manos libres. Por ello, se realizó una revisión sistemática con los siguientes descriptores MeSH: seguridad, eficacia, arteria vertebral. Los artículos obtenidos fueron evaluados por duplicado de forma estandarizada y cegada por dos observadores expertos en análisis sistemático después de la autorización CLEIS 3401 de noviembre de 2014. Por la naturaleza del estudio y las variables no se encontraron artículos con alto nivel de evidencia y grado de recomendación superiores. Nivel de evidencia obtenido sobre la seguridad y eficacia de la colocación de tornillos transpediculares de la columna subaxial con técnica de manos libres: 2b. Grado de recomendación obtenido sobre la seguridad y eficacia de la colocación de tornillos transpediculares en la columna subaxial con técnica de manos libres: B, Recomendación favorable.

Descriptores: Seguridad; Arteria vertebral; Tornillos pediculares; Vértebras cervicales.

Study conducted at the Hospital de Traumatología de la UMAE "Dr. Victorio de la Fuente Narváez", Spine Surgery, IMSS, Mexico, DF.

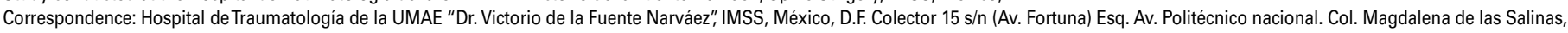
Deleg. Gustavo A. Madero. 07760. dr.cristobalherrera@gmail.com 


\section{INTRODUCTION}

Cervical spinal trauma can result in devastating lesions. Subaxial cervical spine lesions are among the most common spinal cord lesions. ${ }^{1}$ Significant advances have been achieved in our understanding of the biomechanics of the vertebral spine, surgical approaches, and stabilization techniques. ${ }^{2-8}$

When the patient suffers a posterior ligament disruption without irreducible luxation or fracture-luxation with locked facets, the posterior approach is less common. ${ }^{9}$

Numerous stabilization techniques of the cervical spine have been developed, each with its own advantages and limitations. Posterior lateral fixation with screw to the vertebral masses is one of the most commonly used procedures, and offers technical advantages over traditional wire. ${ }^{10,11}$ In cases of osteoporosis or fusion of various levels, loosening of the screws can occur, leading to failure of the fixation. Better stabilization by the posterior route in the subaxial cervical vertebral spine can be achieved by placing the screws in the pedicles, as is done in the thoracic and lumbar spine.

Abumi et al. ${ }^{12,13}$ wrote about their use of transpedicular fixation in the treatment of fractures and luxations of the middle and inferior cervical spine. Several of their patients presented probable perforation of the pedicle due to poor adaptation of the pedicle and screw size, but the vital structures were not damaged.

In modern spine surgery, the best techniques have led to a decrease in surgical complications. Intraoperative imaging tools provide valuable information during instrumentation of the vertebrae. Despite the improved precision that these technologies can offer, their cost may be a limiting factor in many vertebral spine centers. These technologies may also be associated with a higher risk of exposure to radiation and increased surgery times, and the additional hardware may be difficult to manage. It has also been suggested that dependence on these technologies may result in loss of surgeon's skill in the use of spine instrumentation. ${ }^{14,15}$ Fluoroscopy is generally considered the most profitable and popular form of radiology. It is widely recommended to increase the precision in the insertion of pedicle screws in the cervical spine. In the insertion of pedicle screws with fluoroscopy, the rate of perforation of the lateral pedicle wall was reported to be between $6.7 \%$ and $29.8 \% .^{16}$

Jin et al., ${ }^{17}$ using a freehand technique in combination with preoperative computed tomography with $1 \mathrm{~mm}$ cuts, demonstrated a conversion rate to screws in lateral masses of only $5.9 \%$.

The insertion of pedicle screws with the freehand technique in the vertebrae of the subaxial cervical spine can be safe and effective if there is adequate training, similar to that given to surgeons working with the thorocolumbar levels. ${ }^{18}$

Yoshimoto et al. ${ }^{19}$ demonstrated a gradual decrease in the failure rate from $12 \%$ to $1.1 \%$ along the learning curve during 3 periods of practice in the placement of pedicle cervical screws.

Two different methods have been described for inserting the cervical pedicle screws, which vary in location and angle of the insertion of the screw at its point of entry. ${ }^{20}$

Furthermore, some authors have recommended the use of cannulated screws and perforating incisions separated with a trocar system to create a sufficient medial angle and increase the precision of the insertion. ${ }^{15}$ Jin et al. ${ }^{17}$ demonstrated that the screws do not penetrate through the medial wall of the pedicle, and hypothesized that the medial wall of the subaxial cervical pedicle is too thick to penetrate with the pedicle probe and standard insertion force. Furthermore, monitoring of evoked potentials during the surgery can provide useful information on whether the medial wall has been perforated by a screw.

Similar to the report of Jin et al., ${ }^{17}$ many authors have shown that the majority of pedicle perforations occur in the lateral direction, which could result in damage to the vertebral artery.

Jin et al. ${ }^{17}$ believe that lateral fluoroscopic information does not increase the precision rate. Two-dimensional fluoroscopic information can lead to confusion when navigating around the three-dimensional structure of the pedicle. Furthermore, the small size of the subaxial cervical pedicles can hinder the interpretation of the lateral fluoroscopic images in relation to the real anatomy of the pedicle.

In general, the percentage of incorrect placement of pedicle screws can be notoriously high. Moreover, poor placement may result in damage to the nerve and vascular elements. ${ }^{21}$ Even experienced surgeons have rates of medial deviation of the screws of $5 \%$ and inferolateral deviation of $15 \%$ of cases when standard fluoroscopy is used. ${ }^{22}$ It has been demonstrated that perforation of the medical pedicle in excess of $4 \mathrm{~mm}$ can jeopardize the neural elements, resulting in neurological deficits. Although there is no strong evidence in the literature that violation of the pedicle by less than $2 \mathrm{~mm}$ is safe, most surgeons do not consider this pedicle perforation zone to be safe. ${ }^{23}$

In studies using the freehand technique, the percentage of screws totally contained within the pedicle, without perforation, is between $69 \%$ and $94 \%$. In studies of screw insertion guided by fluoroscopy, percentages of between $28 \%$ and $85 \%$ are reported.

The percentage of screws fully contained within the pedicle in studies that use computerized navigation was significantly higher, between $89 \%$ and $100 \%$. Similar results were reported in studies that used navigation guided by fluoroscopy, with $81-92 \%$ of the screws being fully included in the pedicle. ${ }^{24}$

The technical differences present various results with respect to the degree of perforation. Moreover, the percentage of screws that had perforation of $2 \mathrm{~mm}$ was not more than $7 \%$ and $5 \%$ for the computerized navigation and fluoroscopy techniques, respectively. By contrast, the same percentage in studies using fluoroscopy is $28 \%$ and when the freehand technique is used, this percentage rises to $19 \%{ }^{24}$ Gelalis et al. ${ }^{24}$ confirm that navigation systems provide greater precision in the placement of the pedicle screw, as the percentage of screws rated $\mathrm{C}$ (violation of more than $4 \mathrm{~mm}$ ) was also considerably lower in both CT and fluoroscopy-guided navigation, compared with the other techniques.

They found that the rate of neurological complication is similar in studies that use the technique of navigation by computerized tomography, the freehand technique, and fluoroscopy. This corroborates with studies in the literature, which report that the use of navigation systems has not yet led to a decrease in the rate of neurological complications. ${ }^{25}$ Hence the importance of precision in the placement of the screw, which means that the screw is fully included in the pedicle without violating it. The objective of the present study is to identify the level of evidence and level of recommendation of the medical literature in relation to the safety and efficacy of transpedicular instrumentation of the subaxial spine using the freehand technique.

\section{MATERIAL AND METHODS}

This is a systematic review, with a study design that includes six ways of addressing a project: qualitative, retrospective (secondary sources), transversal, multigroup (each search node), and observational. The systematic review was performed from October 2014. The articles obtained were evaluated in duplicate, in the standard,blinded form, by two observers who were experts in systematic analysis, following the CLEIS 3401 authorization in November 2014.

\section{Selection criteria}

Inclusion criteria: Articles and/or abstracts on the results of transpedicular instrumentation in the subaxial spine with the freehand technique. Clinical assays, case studies and controls or cohorts. Articles and/or abstracts of indexed journals (Medline-Pubmed). Articles and/or abstracts published in English or Spanish. Articles and/or abstracts in another language that have an abstract and/or full text in Spanish or English. Exclusion criteria: Articles that do not meet the international rules of bioethics, review articles, articles published in more than one journal (to avoid duplication). Elimination criteria: None, due to the nature of the study. Design and type of sample: non-probabilistic sample, according to the search terms of the MeSH. Calculation of the sample size: The sample was formed according to the articles that meet the selection criteria, based on the search terms of the MeSH.

\section{Methodology}

Generation of search limits through the identification of suitable keywords in the Medical Subject Headings (MeSH). Use of Boolean analysis to identify articles that meet the selection criteria. Analysis 
and weighting of the articles according to the Level of Evidence and Level of Recommendation, as suggested by Sackett. Analysis and weighting of the articles using the Jadad score and the scale proposed for the Torres' level of therapeutic scope (NATT). All the articles were evaluated using the Jadad validation scale by 2 observers in blinded form, as well as the Sackett scale for the evaluation of articles to classify the level of evidence and level of recommendation. The records were emptied in the annexes for their registration of concentrations and analyzed using the statistical evidence of Chi squared inferential analysis. Each article was validated by two reviewers, with previous standardization of the observers.

\section{Analysis of the results}

Descriptive measures of the dependent variables were performed. This was followed by inferential analysis, comparing and adjusting for safety and efficacy of the treatment; also by study group and their specific weight was measured by Level of Evidence and Level of Recommendation.

The interobserver consistency of the evaluations was measured according to Jadad in the articles using the Kappa and weighted Kappa values, with values of $>0.80, p<0.05$ being adequate.

\section{Results of the search method}

A search was carried out on the keywords selected independently, through the $\mathrm{MeSH}$ terms, through the pre-established search trees. 282 articles were obtained, of which 12 met the selection criteria i.e. published between 2000 and 2014, and consisting of 100\% full text.(Table 1)

From the search conducted with the MeSH terms:

- Cervical Pedicle Screw Fixation + Accuracy: 74 results were obtained, of which 70 of the citations were not included because they did not satisfactorily meet the selection criteria, or due to duplication. - Cervical Pedicle Screw Fixation + Security: 74 results were obtained, of which 71 of the citations were not included because they did not meet the search criteria, or due to duplication.

- Cervical Pedicle Screw Fixation + Vertebral Artery: 134 results were obtained, of which 129 of the references were not included because they did not satisfactorily meet the selection criteria, or due to duplication.

\section{Analysis of the data}

Of the studies found, $75 \%$ originated in Asia, $16.6 \%$ in the United States, and $8.4 \%$ in Europe. (Figure 1)

Types of study: The majority were cohort studies (6), case and control studies (0), case series (3) and expert opinions (3). (Figure 2)

Level of evidence: The level of evidence identified was not homogenous, with $2 \mathrm{~b}$ for six articles, 4 for three articles, and 5 for three articles. (Figure 3)

Finally, the level of recommendation for the studies was B for 6 of the 12 articles, $C$ for 3 articles, and D for 3 articles. (Figure 4)

\section{Evaluation of the methodological quality}

Having selected the studies, the methodological quality was evaluated according to JADAD. This evaluation was done independently, in blinded form, with a level of intraobserver agreement of 1. (Table 2)

A low score was obtained according to the JADAD scale for the design of the publications included; for the 12 articles, a score of 0 was obtained.

The evaluation of levels of evidence and level of recommendation of each publication was done using the scale proposed by Sackett. (Table 3) A level of intraobserver correlation of 0.89 was obtained.

Due to the nature of the study and the variables, no articles were found with a higher level of evidence and level of recommendation. The level of evidence obtained on the safety and efficacy in the placement of the transpedicular screws in the subaxial spine using the freehand technique was $2 \mathrm{~b}$.

The level of recommendation obtained on the safety and efficacy in the placement of the transpedicular screws in the subaxial spine with the freehand technique was B: favorable recommendation.

Table 1. Articles included

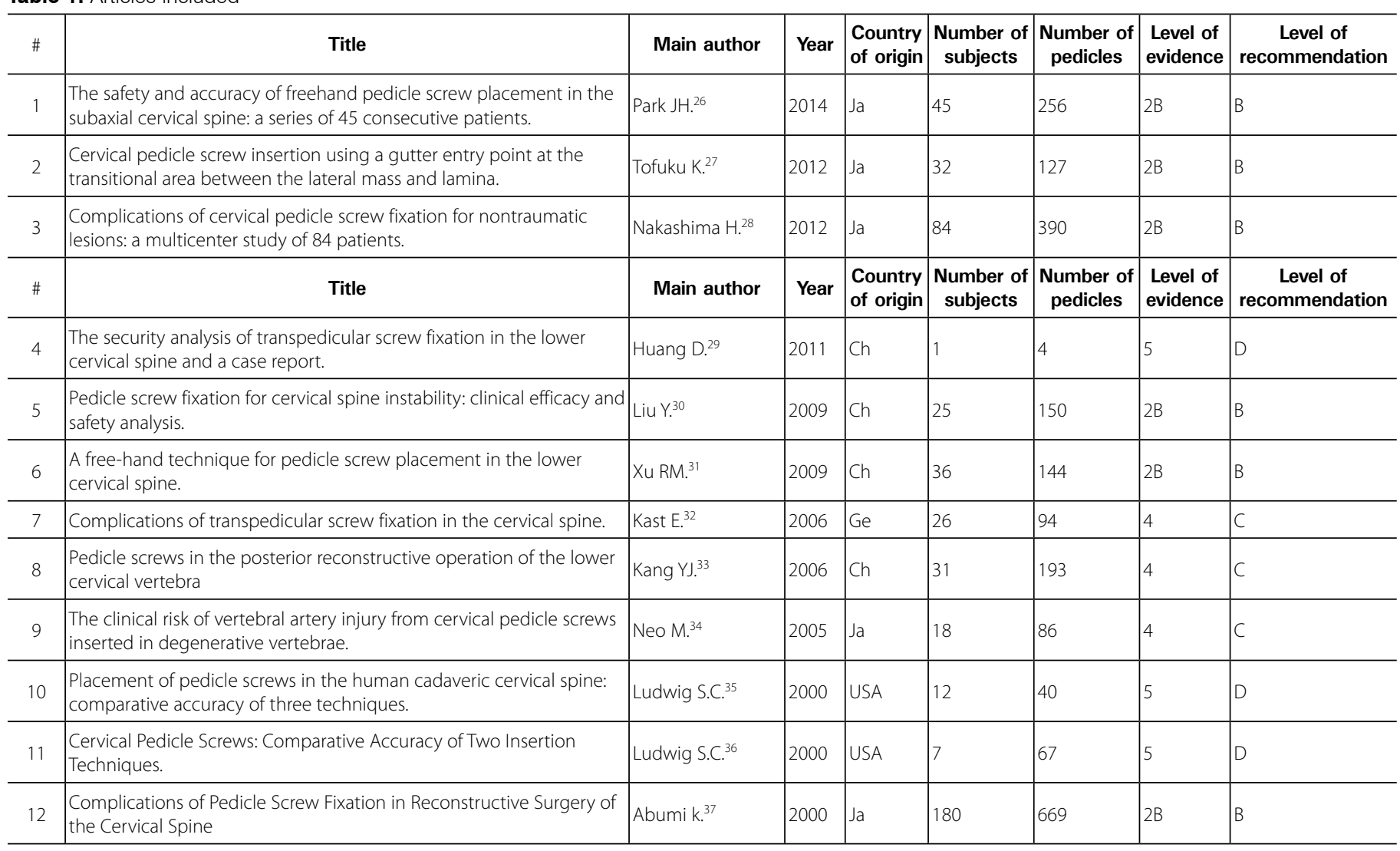




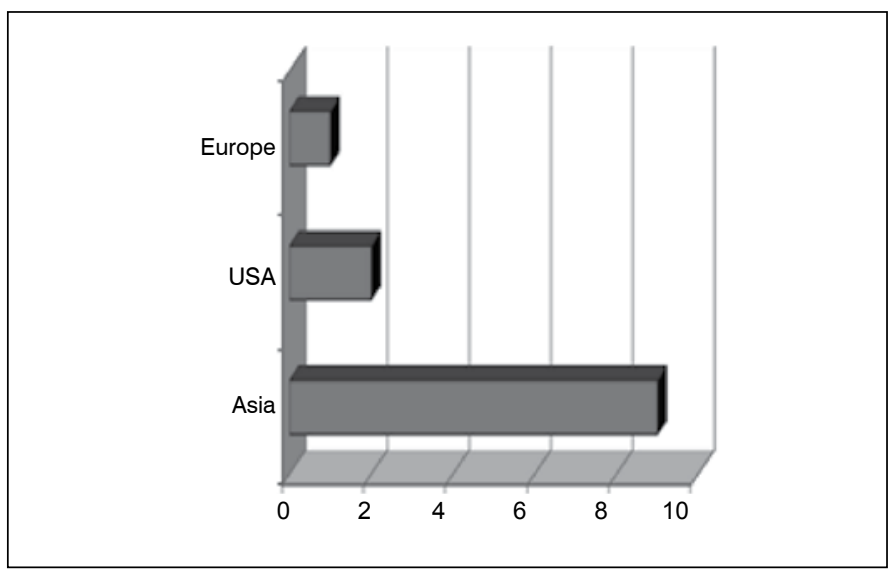

Figure 1. Origin of the articles (China: 4, Japan: 5, USA: 2, Germany: 1).

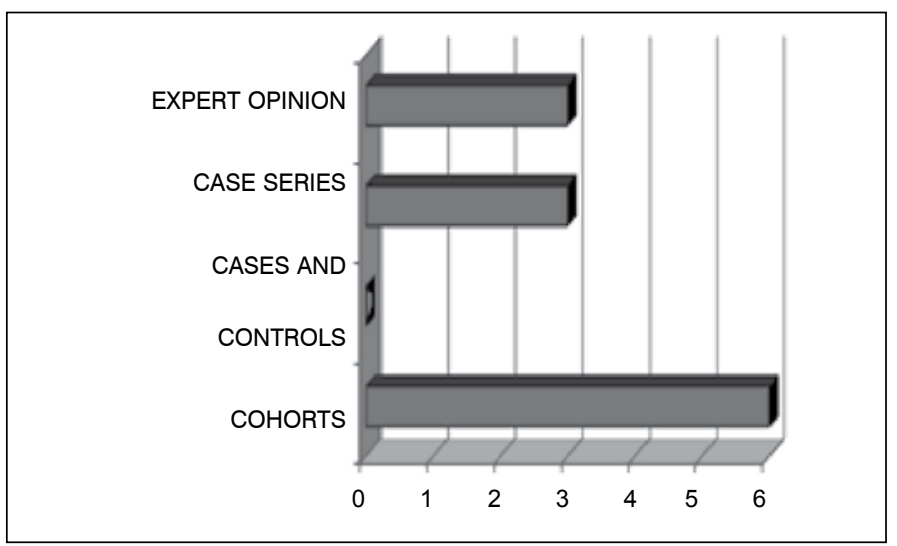

Figure 2. Types of study.

\section{DISCUSSION}

The biomechanical advantages of the fixation with transpedicular screws in the subaxial spine are a stable construct, the reductions of the percentage of pseudoarthrosis, and a better correction of the deformity.

There are few studies in the literature valuate with the appropriate methodology the precision of the insertion of the screw in the pedicle of the subaxial spine.

Although these studies make a significant contribution in decisionmaking in the field of surgery, there are some questions that call for an analysis of methodology and the quality of the articles included. All the studies included were retrospective analyses of the placement of the transpedicular screws in the subaxial spine with the freehand technique. This is its main disadvantage, considering the higher risk of bias that limits the level of evidence.

Moreover, Ludwig S.C et al. include cadaveric studies in their inclusion criteria. In these studies, the results obtained from in vitro surgeries differ significantly from clinical studies. ${ }^{35}$

In the studies that included the patients instrumented with transpedicular screw, the precision of its insertion was evaluated after the surgery with the use of computerized tomography. In the analysis of the articles, some differences were identified in the mean results between the different studies analyzed. These results are generally associated with the heterogeneity between studies, because of the different demographic characteristics of the patients, and the different indications for surgery.

On the other hand, technical questions, such as differences in the surgeons' skills, the variable complexity of the surgery, and the dimensions of the screw in relation to the dimension of the pedicle, may be responsible for this difference in results.

An important finding of studies in relation to screws inserted using

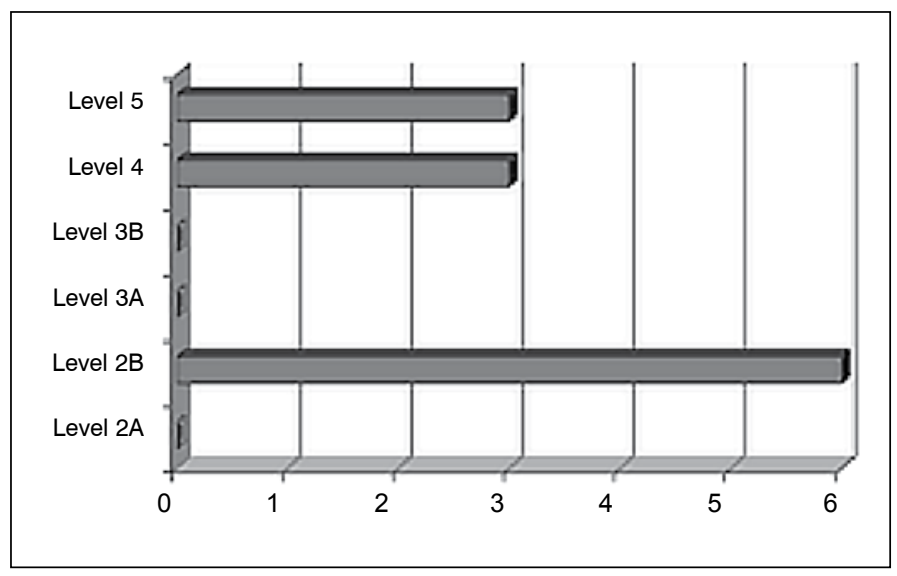

Figure 3. Level of evidence.

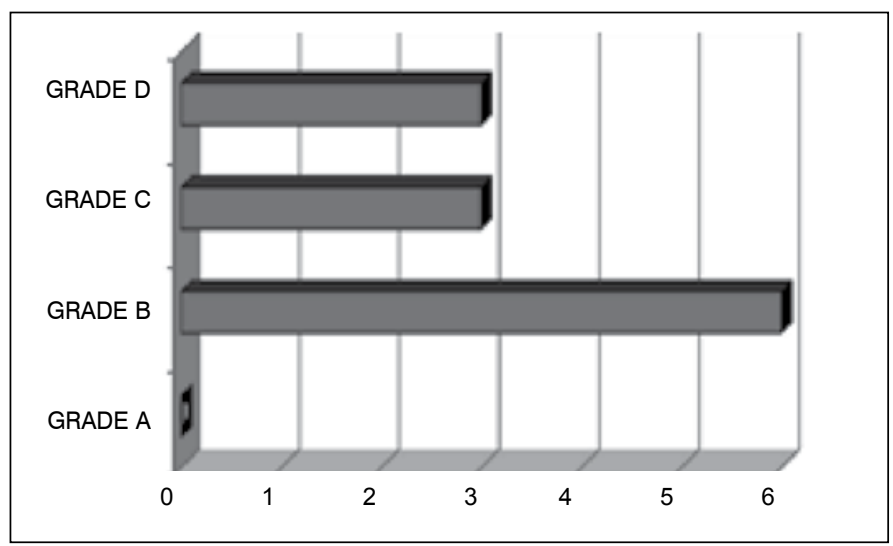

Figure 4. Level of recommendation.

the freehand technique is that they tend to perforate the medial cortex, while screws inserted using computer navigation guidance appear to perforate the lateral cortex more often. However, there is no correlation between any specific technique and the site of perforation of the cortex (medial or lateral).

The reason for the prevalence of medial perforations may be the difference between the axis of the longitudinal midline of the pedicle (ideal trajectory of the screw) and the anatomically practicable axis. When attempting to avoid contact with the facet joint, the surgeon, in some cases, accepts perforation. In other words, these are predictable perforations.

This is inevitable, especially, in cases where the diameter of the screw is close to or larger than the diameter of pedicle isthmus. The importance of precise screw insertion has been emphasized, based on the argument of the rate of complications in cases where the screws are significantly displaced. For this reason, the perforation is classified according to the degree of violation of the cortex.

For the same reason, the term "terminal safe zone" was admitted, but there is no scientific evidence that any degree of perforation is acceptable. It was found that the rate of neurological complications was similar in studies that used the freehand technique and those that used other techniques. This is in accordance with the literature, which reports that the use of navigation systems has not demonstrated any decrease in the rate of neurological complications.

Our results do not show any correlation between the degree of poor positioning of the screw and neurological complications, as reported by similar studies in the field.

This study has recognized limits, such as the few studies included in this analysis that met the selection criteria, reducing the power of the analysis to offer a recommendation about the reason behind the systematic review.

In particular, the notable heterogeneity of the variables for comparison 
Table 2. JADAD score of the publications included.

JADAD Score

\begin{tabular}{|c|c|c|c|c|c|c|c|c|c|c|c|c|c|c|c|c|c|c|c|c|c|c|c|c|}
\hline \multirow{2}{*}{$\begin{array}{l}\text { Article \# } \\
\text { Observer }\end{array}$} & \multicolumn{2}{|c|}{1} & \multicolumn{2}{|c|}{2} & \multicolumn{2}{|c|}{3} & \multicolumn{2}{|c|}{4} & \multicolumn{2}{|c|}{5} & \multicolumn{2}{|c|}{6} & \multicolumn{2}{|c|}{7} & \multicolumn{2}{|c|}{8} & \multicolumn{2}{|c|}{9} & \multicolumn{2}{|c|}{10} & \multicolumn{2}{|c|}{11} & \multicolumn{2}{|c|}{12} \\
\hline & 1 & 2 & 1 & 2 & 1 & 2 & 1 & 2 & 1 & 2 & 1 & 2 & 1 & 2 & 1 & 2 & 1 & 2 & 1 & 2 & 1 & 2 & 1 & 2 \\
\hline Is the study described as randomized? & 0 & 0 & 0 & 0 & 0 & 0 & 0 & 0 & 0 & 0 & 0 & 0 & 0 & 0 & 0 & 0 & 0 & 0 & 0 & 0 & 0 & 0 & 0 & 0 \\
\hline $\begin{array}{l}\text { Is the method used to generate the } \\
\text { randomization sequence described, and } \\
\text { is it adequate? }\end{array}$ & 0 & 0 & 0 & 0 & 0 & 0 & 0 & 0 & 0 & 0 & 0 & 0 & 0 & 0 & 0 & 0 & 0 & 0 & 0 & 0 & 0 & 0 & 0 & 0 \\
\hline Is it described as a double-blind study? & 0 & 0 & 0 & 0 & 0 & 0 & 0 & 0 & 0 & 0 & 0 & 0 & 0 & 0 & 0 & 0 & 0 & 0 & 0 & 0 & 0 & 0 & 0 & 0 \\
\hline $\begin{array}{l}\text { Is the blinding method described, and is } \\
\text { it adequate? }\end{array}$ & 0 & 0 & 0 & 0 & 0 & 0 & 0 & 0 & 0 & 0 & 0 & 0 & 0 & 0 & 0 & 0 & 0 & 0 & 0 & 0 & 0 & 0 & 0 & 0 \\
\hline $\begin{array}{l}\text { Is there a description of losses to follow } \\
\text { up and withdrawals? }\end{array}$ & 0 & 0 & 0 & 0 & 0 & 0 & 0 & 0 & 0 & 0 & 0 & 0 & 0 & 0 & 0 & 0 & 0 & 0 & 0 & 0 & 0 & 0 & 0 & 0 \\
\hline FINAL SCORE & 0 & 0 & 0 & 0 & 0 & 0 & 0 & 0 & 0 & 0 & 0 & 0 & 0 & 0 & 0 & 0 & 0 & 0 & 0 & 0 & 0 & 0 & 0 & 0 \\
\hline
\end{tabular}

Table 3. Sackett Evaluation of the publications included.

\begin{tabular}{c|c|c|c|c}
\hline \multirow{2}{*}{ Article } & \multicolumn{2}{|c|}{ Level of evidence } & \multicolumn{2}{c}{ Level of recommendation } \\
\cline { 2 - 5 } & Observer 1 & Observer 2 & Observer 1 & Observer 2 \\
\hline 1 & $2 B$ & 4 & B & C \\
\hline 2 & $2 B$ & 4 & B & C \\
\hline 3 & $2 B$ & $2 B$ & B & B \\
\hline 4 & 5 & 5 & D & D \\
\hline 5 & $2 B$ & $2 B$ & $B$ & $B$ \\
\hline 6 & $2 B$ & $2 B$ & $B$ & B \\
\hline 7 & 4 & 4 & C & C \\
\hline 8 & 4 & 4 & C & C \\
\hline 9 & 4 & 4 & C & C \\
\hline 10 & 5 & 5 & D & D \\
\hline 11 & 5 & 5 & D & D \\
\hline 12 & $2 B$ & $2 B$ & B & B \\
\hline
\end{tabular}

of the available evidence. This heterogeneity limits a more precise statistical analysis in this systematic review. Other related limitations are the heterogeneity of the study population, the indication for surgery, and the different levels of vertebral spine instrumented.

The small number of pedicles instrumented using the freehand method may also be a factor of heterogeneity in the analysis of the different studies.

Heterogeneity may also relate to the surgeon's skill and ability to evaluate the length and diameter of the screw in relation to the pedicle.

\section{FINAL CONSIDERATIONS}

Because of the systematic review of the literature, 12 articles with inclusion criteria were identified. Based on the analysis of their quality, it was determined that the methodology used in them is poor. Due to their poor methodological quality, the articles did not enable a consistent recommendation to be made for the freehand technique in transpedicular instrumentation of the subaxial vertebral spine. Prospective studies are needed, with better methodological quality and long-term follow-up, to adequately identify the results in terms of safety and efficacy of the freehand technique in the transpedicular instrumentation of the subaxial vertebral spine.

All authors declare no potential conflicts of interest concerning this article.

AUTHORS' CONTRIBUTION: Each author contributed individually and significantly to the development of the manuscript: CHP, AFRG, GCM and AGM were responsible for the concept and design of the study. CHP and AFRG performed the critical review. SFF carried out the data analysis and interpretation. 


\section{REFERENCES}

1. Goldberg W, Mueller C, Panacek E, Tigges S, Hoffman JR, Mower WR, et al. Distribution and patterns of blunt traumatic cervical spine injury. Ann Emerg. 2001;38(1):17-21.

2. Aebi M, Zuber K, Marchesi D. Treatment of cervical spine injuries with anterior plating. Indications, techniques, and results. Spine (Phila Pa 1976). 1991;16(Suppl 3):S38-45.

3. Do KohY, Lim TH, Won You J, Eck J, An HS. A biomechanical comparison of modern anterio and posterior plate fixation of the cervical spine. Spine (Phila Pa 1976). 2001;26(1):15-21.

4. Dvorak MF, Fisher CG, Fehlings MG, RampersaudYR, Oner FC, Aarabi B, et al. The surgical approach to subaxial cervical spine injuries: an evidence-based algorithm based on the SLIC classification system. Spine (Phila Pa 1976). 2007:32(23):2620-9.

5. Henriques T, Olerud C, Bergman A, Jónsson H Jr. Distractive flexion injuries of the subaxial cervical spine treated with anterior plate alone. J Spinal Disord Tech. 2004;17(1):1-7.

6. Lambiris E, Kasimatis GB, Tyllianakis M, Zouboulis P, Panagiotopoulos E. Treatment of unstable lower cervical spine injuries by anterior instrumented fusion alone. J Spinal Disord Tech. 2008;21(7):500-7.

7. Woodworth RS, Molinari WJ, Brandenstein D, Gruhn W, Molinari RW. Anterior cervical discectomy and fusion with structural allograft and plates for the treatment of unstable posterior cervical spine injuries. J Neurosurg Spine. 2009;10(2):93-101.

8. Kwon BK, Vaccaro AR, Grauer JN, Fisher CG, Dvorak MF. Subaxial cervical spine trauma. J Am Acad Orthop Surg. 2006:14(2):78-89.

9. Pateder DB, Carbone JJ. Lateral mass screw fixation for cervical spine trauma: associated complications and efficacy in maintaining alignment. Spine J. 2006;6(1):40-3.

10. Gill K, Paschal S, Corin J, Ashman R, Bucholz RW. Posterior plating of the cervical spine. A biomechanical comparison of different posterior fusion techniques. Spine (Phila Pa 1976). 1988;13(7):813-6.

11. Roy-Camille R, Saillant G, Mazel C. Internal fixation of the unstable cervical spine by a posterior osteosynthesis with plate and screw. In: Cervical Spine Research Society (editors). The cervical spine. Philadelphia: Lippincott; 1989. p. 390-403.

12. Abumi $\mathrm{K}$, Itoh $\mathrm{H}$, Taneichi $\mathrm{H}$, Kaneda K. Transpedicular screw fixation for traumatic lesions of the middle and lower cervical spine: description of the techniques and preliminary report. J Spinal Disord. 1994:7(1):19-28.

13. Abumi K, Kaneda K. Transpedicular screw fixation for reconstruction of the cervical spine. In: Annual meeting of the America Academy of Orthopedic Surgeons, Orlando, Florida, 1 a 5 março, 1995.

14. Johnston TL, Karaikovic EE, Lautenschlager EP, Marcu D. Cervical pedicle screws vs. lateral mass screws: uniplanar fatigue analysis and residual pullout strengths. Spine J. 2006:6(6):667-72

15. Richter M, Cakir B, Schmidt R. Cervical pedicle screws: conventional versus computerassisted placement of cannulated screws. Spine (Phila Pa 1976). 2005;30(20):2280-7.

16. Yukawa Y, Kato F, Yoshihara $H$, Yanase M, Ito K. Cervical pedicle screw fixation in 100 cases of unstable cervical injuries: pedicle axis views obtained using fluoroscopy. J Neurosurg Spine. 2006;5(6):488-93.

17. Park JH, Jeon SR, Roh SW, Kim JH, Rhim SC. The safety and accuracy of freehand pedicle screw placement in the subaxial cervical spine: a series of 45 consecutive patients. Spine (Phila Pa 1976). 2014;39(4):280-5.

18. Parker SL, McGirt MJ, Farber SH, Amin AG, Rick AM, Suk I, et al. Accuracy of free-hand pedicle screws in the thoracic and lumbar spine: analysis of 6816 consecutive screws. Neurosurgery. 2011:68(1):170-8.

19. Yoshimoto H, Sato S, Hyakumachi T, Yanagibashi Y, Kanno T, Masuda T. Clinical accuracy of cervical pedicle screw insertion using lateral fluoroscopy: a radiographic analysis of the learning curve. Eur Spine J. 2009;18(9):1326-34.

20. Abumi K, Ito M, Sudo H. Reconstruction of the subaxial cervical spine using pedicle screw instrumentation. Spine (Phila Pa 1976). 2012;37(5):E349-56.

21. Castro WH, Halm H, Jerosch J, Malms J, Steinbeck J, Blasius S. Accuracy of pedicle screw placement in lumbar vertebrae. Spine (Phila Pa 1976). 1996;21(11):1320-4.

22. Mirza SK, Wiggins GC, Kuntz C 4th, York JE, Bellabarba C, Knonodi MA, et al. Accuracy of thoracic vertebral body screw placement using standard fluoroscopy, fluoroscopic image guidance, and computed tomographic image guidance: a cadaver study. Spine (Phila Pa 1976). 2003;28(4):402-13.

23. Kim YJ, Lenke LG, Bridwell KH, Cho YS, Riew KD. Free hand pedicle screw placement in the thoracic spine: is it safe? Spine (Phila Pa 1976). 2004:29(3):333-42.

24. Gelalis ID, Paschos NK, Pakos EE, Politis AN, Arnaoutoglou CM, Karageorgos AC, et al. Accuracy of pedicle screw placement: a systematic review of prospective in vivo studies comparing free hand, fluoroscopy guidance and navigation techniques. Eur Spine J. 2012;21(2):247-55

25. Gaines RW Jr. The use of pedicle-screw internal fixation for the operative treatment of spinal disorders. J Bone Joint Surg Am. 2000; 82(10):1458-76.

26. Park JH, Jeon SR, Roh SW, Kim JH, Rhim SC. The safety and accuracy of freehand pedicle screw placement in the subaxial cervical spine: a series of 45 consecutive patients. Spine (Phila Pa 1976). 2014; 39(4):280-5.

27. Tofuku K, Koga H, Komiya S. Cervical pedicle screw insertion using a gutter entry point at the transitional area between the lateral mass and lamina. Eur Spine J. 2012;21(2):353-8.

28. Nakashima H, Yukawa Y, Imagama S, Kanemura T, Kamiya M, Yanase M, et al. Complications of cervical pedicle screw fixation for nontraumatic lesions: a multicenter study of 84 patients. J Neurosurg Spine. 2012;16(3):238-47.

29. Huang D, Du K, Zeng S, Gao W, Huang L, Su P. The security analysis of transpedicular screw fixation in the lower cervical spine and a case report. Spine (Phila Pa 1976). 2011;36(26):E1702-8

30. . Liu Y, Hu JH, Yu KY. Pedicle screw fixation for cervical spine instability: clinical efficacy and safety analysis. Chin Med J. 2009;122(17): 1985-9.

31. Xu RM, MaWH, Wang $Q$, Zhao LJ, HuY, Sun SH. A free-hand technique for pedicle screw placement in the lower cervical spine. Orthop Surg. 2009; 1(2):107-12.

32. Kast E Mohr K, Richter HP, Börm W.. Complications of transpedicular screw fixation in the cervical spine. Eur Spine J. 2006;15(3):327-34.

33. Kang YJ, Kong JH, Lü GH, Wang B, Wang WC, Li J. Pedicle screws in the posterior reconstructive operation of the lower cervical vertebra. Zhong Nan Da Xue Xue Bao Yi Xue Ban.2006;31(6):906-10, 920.

34. Neo M, Sakamoto T, Fujibayashi S, Nakamura T. The clinical risk of vertebral artery injury from cervical pedicle screws inserted in degenerative vertebrae. Spine (Phila Pa 1976). 2005;30(24):2800-5.

35. Ludwig SC, Kramer DL, Balderston RA, Vaccaro AR, Foley KF, Albert TJ. Placement of pedicle screws in the human cadaveric cervical spine: comparative accuracy of three techniques. Spine (Phila Pa 1976). 2005;25(13):1655-67.

36. Ludwig SC, Kowalski JM, Edwards CC 2nd, Heller JG. Cervical Pedicle Screws: Comparative Accuracy of Two Insertion Techniques. Spine (Phila Pa 1976). 2005:25(20):2675-81.

37. Abumi $K$, Shono Y, Ito M, Taneichi $H$, KotaniY, Kaneda K. Complications of Pedicle Screw Fixation in Reconstructive Surgery of the Cervical Spine. Spine (Phila Pa 1976). 2005;25(8):962-9. 